\title{
Women, Development, and Flooding Disaster Research in Nigeria: A Scoping Review
}

\author{
Adaku Jane Echendu \\ School of Environmental Studies, Queen's University, Kingston, Ontario, Canada
}

Corresponding Author Email: adaku.chyoma@gmail.com

\section{https://doi.org/10.18280/eesrj.080401}

Received: 24 November 2021

Accepted: 23 December 2021

\section{Keywords:}

gender representation, sustainable development, gender and development, Sendai framework, urban flooding, disaster risk, disaster vulnerabilities, gender analysis

\begin{abstract}
The growing threat of disasters caused by climate change, of which flooding is the most prevalent has led to a call for a change in the design of, and roll-out of disaster mitigation and response policies. A more inclusive approach to Disaster Risk Reduction has been advocated with the Sendai Framework for Disaster Risk Reduction calling for the involvement of women and marginalized groups for more effectiveness and efficiency. The rapidly urbanizing countries of sub-Saharan Africa are particularly vulnerable to the threats and impacts of disasters, including flooding, and women in these countries are differentially vulnerable and marginalized. In response to the call for the inclusion of women in disaster risk management, this scoping review seeks to understand to what extent Nigerian women have been engaged or included in urban flooding research. This review finds that very little research has been conducted on gender and flooding. In addition, $85 \%$ of the papers reviewed focus on rural women, while the prevalence and rising threats of flooding in urban areas are given little attention. As urban centers throughout the region are becoming more feminized, a better understanding of urban women's experiences with flooding will help ensure a more inclusive and effective disaster response.
\end{abstract}

\section{INTRODUCTION}

Disasters are becoming more common with climate change. More than 1.5 billion people globally from the year 2000 to 2012 have been impacted by disasters in different ways, with people in vulnerable situations, women, and children being disproportionately impacted [1]. Of all disasters, flooding has affected people more than any other environmental disaster, impacting social, economic, and environmental sustainability, and hindering sustainable development [2-4]. Africa is predicted to become a future flooding hotspot due to climate change and socioeconomic factors [5, 6]. Yet, flood exposure trends are likely underestimated in rapidly urbanizing countries and underrepresented in the Global Flood Database [2]. This is true for Nigeria, where flood data collection and reporting are poor despite the disaster ravaging the country on an annual basis [7, 8].

Countries under the auspices of the United Nations (UN) are collaborating to seek solutions for disaster risk reduction (DRR). The current UN framework on DRR is the Sendai Framework for Disaster Risk Reduction (SFDRR). The SFDRR calls for a broader and more people-focused preventive strategy to managing disaster risk. It highlights that disaster risk reduction practices need to be multisectoral and multi-hazard, accessible and inclusive for efficiency and effectiveness [9]. Priority 1 of the SFDRR specifically calls for understanding disaster risk in all its elements. To achieve this, all the dimensions of disaster vulnerability, exposure of both persons and assets, hazard attributes and the environment must be understood. Knowledge gained would inform predisaster risk assessment, prevention, mitigation, as well as the development and execution of suitable preparedness and practical response to disasters.

Priority 4 of the SFDRR also centers on improving disaster preparedness to achieve effective response and to "Build Back Better" in recovery, reconstruction, and rehabilitation. According to the framework, this entails empowering women and persons with disabilities to promote and lead universally accessible and gender-equitable response, rehabilitation, recovery, and reconstruction. Gender inequality studies have shown that women in developing nations are more affected by disasters as a result of socio-economic disadvantages and their reliance on the natural environment for carrying out traditional chores [10]. Women in the global south are particularly vulnerable to disaster risks due to the lopsided and highly unbalanced gender norms and discrimination [11]; as well as their inhabitancy of more high-risk marginal locations [12]

Indeed, vulnerabilities to climate disasters are gendersensitive such that women are up to 14 times more likely to die as a result of a disaster in comparison to men [13, 14]. Also, research has shown that women have significantly poorer well-being and mental health outcomes post-disaster, an outcome that deserves further attention [15]. While women are more vulnerable to disasters, their participation has also been recognized as critical to effectively managing disaster risk and designing and implementing gender-sensitive disaster risk reduction policies, plans, and programs; and adequately building capacity measures [10]. This is because local women possess superior organizational networks and social ties which are key factors for promoting sustainable change in DRR [16].

Working with and empowering traditionally marginalized groups such as women who are more vulnerable to disasters can help ameliorate overall impacts. With the rising climate threats and the associated rise in disasters predicted, engaging 
with and involving women in research geared towards influencing policy and planning on climate change is critical to managing disaster risk. As part of a larger body of work on flooding in Nigeria, this work is a scoping review that seeks to understand how women have been engaged in flooding research in Nigeria. This will help identify gaps and direct research and action in deficient areas to better guide policymaking as we seek to move towards a more sustainable future. This is also necessary to design measures to reduce women's vulnerabilities while empowering them to continue to take up leading roles in preparedness and flood mitigation and hence reinforce their capacity to manage disasters.

This paper first touches upon the broader context of gender and development in Nigeria before turning to the review of the specific literature on gender, disaster, and flooding. The key findings are then discussed. The paper concludes by summarizing the key points. A call is made to expand women's participation in disaster research and to engage with urban women who are increasingly experiencing flooding as the papers in this study mainly engaged with rural women.

\section{GENDER AND DEVELOPMENT}

Gender is taken here to mean "the social, behavioral, and cultural attributes, expectations, and norms associated with being a woman or a man" [17]. Development is the reduction and eradication of malnutrition, early death, squalor, illiteracy, disease, and gross inequalities in income and participation and recognition in the political process; and the gradual advancement and evolvement of all political, economic, sociocultural, and other institutional realms of the society for humanity's benefit $[18,19]$. Today, development is geared towards achieving long-term sustainability. It is concerned with the realization of multi-fold development and environmental goals [20]. Women's empowerment in Africa is intricately linked to the development discourse because gender inequalities are a development barrier [21]. Women in the global south are particularly more vulnerable to disaster risks due to the lopsided and highly unbalanced existing gender norms and discrimination [11]; as well as their inhabitancy of more high-risk marginal locations [12]. Notwithstanding, there are few gender-sensitive disaster management measures or policies that consider gender relations $[12,22]$.

There is the view that the Nigerian political discourse and imagination that precludes women as political subjects is partly rooted in the gendered emergence of the Nigerian state [23]. This is because pre-colonialism, women were an integral part of the decision-making in the traditional society playing recognized active roles in the political and religious spheres contrary to the situation in the West [24]. According to Aina [24], in the pre-colonial era, men's and women's spheres of activity were complementary, but this does not imply there was equality between the sexes at the time. The extent of inequality varied depending on, geographical location, ethnic group, historical epoch, and social class. Aina sheds light on the various activities that women of the three major ethnic groups were engaged in. The Igbo women were involved in various industries, the Yoruba women were actively involved in agriculture and trade, while the Hausa-Fulani women also participated in the pastoral and sedentary agricultural system with variations depending on the extent of seclusion practiced in the locality.
The Indirect rule governance style adopted by colonial administrators put men at the helm of local affairs. Women were not accorded any leadership roles despite the fact women were an integral part of leadership in many pre-colonial tribes and ethnic groups. The British rulers simply overlaid the Victorian ideologies of gender in Nigeria and it became unheard of for women to occupy public office as that was also the case in Britain at the time where women held no public office at any level [25]. Domesticity was highly promoted in the 19th and 20th Centuries with women charged with occupying the domestic front while men occupied the public front. The Victorian ideals of gender were also enshrined in the Nigerian education system as seen in the gendered 1909 code of education where girls were trained to be good mothers and wives and boys trained to become professionals [26]. In sum, women were rendered invisible in colonial Nigeria. Whatever power or control they had over their affairs precolonialism became unimportant and the voice and representation they exercised in decision making became subsumed under the colonial government. The traditional recognition accorded women via their various activities was rendered useless and irrelevant in the colonial era. The inherited legacy of inequality has been further nurtured by various socio-political actions since Nigeria's independence which has been viewed as a mere change of guard given that the colonial government's positioning of women as subordinates to men has persisted post-colonization; leading to the now largely entrenched marginalization of women [27, 28]. Arguably, women's marginalization that has become entrenched in the Nigerian societal fabric is one of the factors that makes them more vulnerable to disasters. Several studies support this and have shown that the gendered division of labor particularly with regard to care-giving responsibilities and roles often raise women's pre-disaster vulnerability and also places additional hardship on women during disaster recovery [29-31]

In flooding research specifically, inadequate attention has been paid to women's experiences. While flooding impacts transcends gender, the manner and scale of impacts are not gender-neutral $[14,32]$. This implies that for a better and holistic understanding of flooding disasters, incorporating a gender analysis is vital. For effective DRR as well, it is crucial to ensure women are actively engaged. Women can use their power to create and protect resources that can mitigate potential harm in the event of a disaster [10]. This implies that a commitment to better understand the environment within which a disaster study takes place is crucial for targeted and effective interventions.

\section{RESEARCH METHOD}

Scoping reviews are ideal for ascertaining the coverage, overview, and studies available of a given topic [33]. They are useful for identifying, mapping, and analyzing knowledge gaps but do not aim to produce a critically synthesized and appraised answer to specific questions [33-35]. The objective is to provide an overview of a body of literature in relation to location, time, etc. [36]. In this study, the goal is to examine the body of literature that has so far engaged with women in flooding research in Nigeria. Using the Population, Concept, and Context method [33] to guide this scoping review, our population in this study is women. The concept is flooding while the context is Nigeria. Scoping reviews require 
transparent and rigorous methods in their conduct to assure that the findings are trustworthy [33]. We, therefore, used these keywords as our search terms: 'women', 'flooding', and 'Nigeria' to conduct a database search in the Web of Science database. There were no restrictions/parameters set for the year of publication. The database search generated 13 results. Of the 13 results, only 6 were focused on flooding and gender in Nigeria. Three were studies conducted in Anambra state, one in Ebonyi state, one in Lagos, and another in an unspecified part of northern Nigeria. A search in the ProQuest database using the same search terms for peer-reviewed literature generated 1,185 results. However, the results were not as streamlined as the Web of Science database search which all focused on flooding. The majority of the literature was unrelated to flooding and not all focused on Nigeria. All the results in the web of science database also appeared in the ProQuest database. A further hand search of the literature yielded one relevant paper with research conducted in Bayelsa State which was also included in this review. Table 1 below showcases the final search results.

\section{DISCUSSION}

The results obtained highlighted the paucity of genderfocused disaster research in Nigeria. This is in congruence with earlier work that found there were few gender-sensitive city-scale research, disaster management, and climate measures or policies that consider lopsided power relations, labor divisions, and societal roles $[12,22]$. While the need to accord more attention to gender research to elevate the place and status of women in all spheres of life is recognized in various international policy documents, not much has been done in this area in disaster research in Nigeria. For instance, goal 5 of the United Nations (UN) sustainable development goals (SDGs) specifically seeks to empower all women and girls. One way of fostering this empowerment is by making sure women's voices are heard especially in research that seeks to ultimately inform policy in the pursuit of development.

The different studies reviewed highlighted the vulnerabilities women face due to flooding. All but one of the papers focused on women farmers in rural parts of Nigeria.

The engagement and focus on women farmers support evidence in the literature that rural producers were mostly women [24]. It also supports earlier findings that the majority of climate and gender studies in Nigeria and Africa at large focused on rural women in the natural resource and agricultural sector with little information about women in urban areas [31]. It is not promising that eight years since the finding by Ajibade et al. [31], there is still a dearth of research in this area, especially in the light of rising disaster threats that disproportionately impact women in the global south.

A recurrent theme was the denial of property and land ownership rights to women even as the rural women primarily depended on the land for livelihood. This increases their dependence on men for access to farmlands which increases their vulnerabilities. Ajaero [13] studied the rural women farmers with lived experiences of flooding highlighted the numerous ways their status as women disadvantaged them further post-flooding disasters. While men were able to diversify their income sources to cushion the impact of future flooding on farm produce, some of the women did not have the same privilege as some of the jobs were not deemed gender appropriate for women. Others were reluctant to invest their little income in farming activities fearing floods will happen again and wash away their sweat and investments. This is in congruence with studies on societal expectations of women's participation in the labor force in many African countries and also with the gendered division of duties where women are discouraged from partaking in certain industries [26, 37, 38]. Most of the rural women in the study [13] did not have western education and the jobs men turned to post-flooding disasters like carpentry were not jobs women were expected to perform. Those women employed in the civil service who also took up farming activities fared much better. A similar finding was made by Enete et al. [39] among farming households in Anambra state where men were more likely to be involved in other non-farm industries than women which helped them adapt better to recurrent floods. Domestic tasks which rural women mostly combine with farm work made it harder for them to engage in non-farm activities. In the works of Nnadi et al. [40] on climate variability impacts among rural residents in Anambra state as well, women were also more negatively impacted than men. Among women traders in Bayelsa state, flooding also adversely affected their livelihood patterns [41].

Ajibade et al. [31], in their research to understand the patterns of vulnerability and resilience to flooding among women in different communities in Lagos Nigeria, found that the women, in general, did not see themselves as being differently impacted from men. The authors attribute this to the deeply ingrained gender responsibilities and roles in the Nigerian society which have led women to accept that the additional roles they take up are natural, thus flood impacts were not socially constructed but natural.

Also, the women's view in the study [31] that flood impacts were gender-neutral was not supported by research evidence as the researchers found that impacts of flooding varied by gender, income, and even according to neighborhoods. While gender alone is not a significant determinant of vulnerability to flooding impacts, gendered experiences of flooding are influenced by gender roles which intersect with class, place, and household structure. Low-income women experienced the worst effects of flooding and gendered impacts in a disaster context.

However, Ibrahim et al. [42] in their work concluded that disasters have only a moderate impact on inter-gender income variances but rather, a larger proportion of inequalities are explained by demographic factors. To them, a male-female dualistic construct fosters neglect of intra-gender disparities in designing and implementing DRR policies. They posit that interventions should be dependent on households' human, social and economic capital and not solely focus on gender. Certainly, disaster research ought not to focus on gender alone. However, the manner and scale of impact are not genderneutral [14, 32], and deserve attention for effective response contrary to their position.

There are also clearly intra-gender disparities in support of the position by Ibrahim et al [42]. Gendered disaster experience intersects with class, position, and place. This has been affirmed in research by Ajibade et al. [31] who studied flooding impacts among women of different economic means. Gender roles and relations intersected with class, place, employment status and exposed low-income women to more risks and impacts than higher-income women. The lowerincome women in poor neighborhoods experienced much more impacts and slower recovery in comparison to women in higher-income neighborhoods.

Just as Akinsemolu and Olukoya [43] highlighted that an 
understanding of women's vulnerabilities to climate effects is best produced in the nexus between the contextual analysis of climate change variables and a localized study of differentiation in patriarchal norms, gender roles, and other unknown factors within a particular setting; the same is true for those disasters like flooding which is also linked to climate change.

The SFDRR calls for empowering women to publicly lead and contribute toward the design of gender-sensitive DRR plans, policies, and programs [44], but a lot still needs to be done with women to better understand the optimal ways of addressing and implementing flood mitigation measures.

Table 1. List of papers in the scoping review

\begin{tabular}{|c|c|c|c|}
\hline Author & $\begin{array}{c}\text { Title } \\
\end{array}$ & Year & Place \\
\hline $\begin{array}{l}\text { Akintoye et al. } \\
\text { [14] }\end{array}$ & $\begin{array}{c}\text { Socio-Economic Implications of Recurrent Flooding on Women Development in Southern Ijaw } \\
\text { Local Government Area, } \\
\text { Bayelsa State, Niger Delta Area of Nigeria }\end{array}$ & 2016 & Bayelsa \\
\hline $\begin{array}{l}\text { Ajibade et al. } \\
\text { [31] }\end{array}$ & Urban flooding in Lagos, Nigeria: Patterns of vulnerability and resilience among women & 2013 & Lagos \\
\hline $\begin{array}{l}\text { Enete et al. } \\
\text { [39] }\end{array}$ & Socioeconomic assessment of flooding among farm households in Anambra state, Nigeria & 2016 & Anambra \\
\hline Ajaero [13] & $\begin{array}{l}\text { A gender perspective on the impact of flood on the food security of households in rural } \\
\text { communities of Anambra state, Nigeria }\end{array}$ & 2017 & Anambra \\
\hline $\begin{array}{l}\text { Nnadi et al } \\
\quad[40]\end{array}$ & Impacts of variability and change in rainfall on gender of farmers in Anambra, Southeast Nigeria & 2019 & Anambra \\
\hline $\begin{array}{l}\text { Ibrahim et al. } \\
{[42]}\end{array}$ & $\begin{array}{c}\text { Vulnerability to recurrent shocks and disparities in gendered livelihood diversification in remote } \\
\text { areas of Nigeria }\end{array}$ & 2019 & $\begin{array}{c}\text { Northern } \\
\text { Nigeria }\end{array}$ \\
\hline 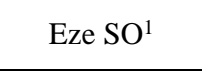 & $\begin{array}{c}\text { Constraints to climate change adaptation among cassava women farmers: implications for } \\
\text { agricultural transformation and food security in Ebonyi state, Nigeria }\end{array}$ & 2017 & Ebonyi \\
\hline
\end{tabular}

\section{CONCLUSION}

Despite the recognized need for understanding the gender dimensions of disasters to better guide DRR, mainstream research on flooding has mainly adopted a neutral approach. While flooding indeed has impacts regardless of gender, it is crucial to take a disaggregated approach for a more tailored mitigation and policy response. Reducing vulnerability is a proven effective and efficient way of ameliorating disaster impacts, and working with women who are a more vulnerable group is certainly an approach that will yield ripple positive dividends even beyond DRR. DRR policy interventions also need to address those root causes of women's marginalization and vulnerability to disasters in Nigeria. Denial of property and land rights to Nigerian women is one of the factors. Reform of land and property rights on a nationwide basis is thus paramount and there needs to be support and advocacy to achieve this.

This work has other important implications. By reviewing the available gender-focused research on flooding, we now have a concise picture of available knowledge and gaps which would help chart the course for future work in this important domain. More engagement with vulnerable and marginalized women which the SFDRR already advocates cannot be overemphasized. The responsibility lies with governments, universities, research institutions, and other relevant stakeholders to address this gap.

As this paper has showcased, there exists only a handful of research studies on flooding in Nigeria with a gender lens. This necessitates more attention to investigating and understanding the ways women navigate and adapt to disasters. Most of the work has also focused on women farmers in rural areas. However, urban flooding is a growing threat with the population of women in African urban areas growing. Those women engaged in supplementary income-generating activities in the papers reviewed in this work were able to better withstand the impacts of flooding. This suggests providing women support and training to engage in other jobs to supplement farming activities would improve their resilience to the perennial threats of flooding.

It is particularly necessary to engage with women in patriarchal societies like Nigeria where women suffer marginalization because of the dominant view that women are inferior to men and should only be seen and not heard. This has generally led to them being excluded in policy-making and project implementation despite their key role in climate emergency responses, knowledge, and leadership abilities [43] Their higher vulnerability to disasters is mainly due to limited economic, social, political, cultural status and lesser opportunities accorded them [14, 31]. These factors need to be addressed.

Gender analysis needs to be a key part of DRR but this aspect is still deficient in Nigeria. This may be related to the fact that the larger society is still run with the patriarchal ideology that largely excludes women in decision-making processes. More attention is needed in the area of understanding disaster vulnerabilities, resilience, adaptation, and mitigation. This can yield important knowledge to inform sustainable environmental management practices and planning in the face of growing climate threats. Building resilience to disasters and emergencies is imperative. To achieve this, involving women more in research aimed at improving disaster resilience is crucial. A shift of focus from rural to urban areas is called for given the high population of urban areas that makes flood impacts much more serious. This is also important as the majority of the population will continue to reside in urban areas amid climate threats. Also, including women in formal disaster planning and policy is an area that needs urgent improvement in future public policy with the formulation of guidelines that demand equal participation of women and men in disaster policy-making necessary. It would be insightful to conduct similar studies in other countries to have a better overview of gaps. This would help ascertain areas to direct research and response which is 
important to achieve the global goals of DRR and sustainability which are interlinked.

\section{ACKNOWLEDGMENT}

I hereby acknowledge the contributions of my Supervisor Dr. Allison Goebel in this work. I am profoundly grateful for her continued guidance and mentorship.

\section{REFERENCES}

[1] Aitsi-Selmi, A., Egawa, S., Sasaki, H., Wannous, C., Murray, V. (2015). The Sendai Framework for disaster risk reduction: Renewing the global commitment to people's resilience, health, and well-being. International Journal of Disaster Risk Science, 6(2): 164-176. https://doi.org/10.1007/s13753-015-0050-9

[2] Tellman, B., Sullivan, J.A., Kuhn, C., et al. (2021). Satellite imaging reveals increased proportion of population exposed to floods. Nature, 596(7870): 80-86. https://doi.org/10.1038/s41586-021-03695-w

[3] Echendu, A.J. (2020). The impact of flooding on Nigeria's sustainable development goals (SDGs). Ecosystem Health and Sustainability, 6(1): 1791735. https://doi.org/10.1080/20964129.2020.1791735

[4] Echendu, A., Georgeou, N. (2021). Not Going to Plan': Urban planning, flooding, and sustainability in Port Harcourt City, Nigeria. Urban Forum, 32: 311-332. https://doi.org/10.1007/s12132-021-09420-0

[5] Merz, B., Blöschl, G., Vorogushyn, S., et al. (2021). Causes, impacts and patterns of disastrous river floods. Nature Reviews Earth \& Environment, 2(9): 592-609. https://doi.org/10.1038/s43017-021-00195-3

[6] Echendu, A.J. (2021). Flooding in Nigeria and Ghana: Opportunities for partnerships in disaster-risk reduction. Sustainability: Science, Practice and Policy, 18(1): 1-15, https://doi.org/10.1080/15487733.2021.2004742

[7] Lucas, B. (2021). Urban flood risks, impacts, and management in Nigeria. K4D Helpdesk Report 948. Institute of Development Studies., Brighton, UK. https://doi.org/10.19088/K4D.2021.018

[8] Echendu, A.J. (2021). Relationship between urban planning and flooding in Port Harcourt city, Nigeria; insights from planning professionals. Journal of Flood Risk Management, 14(2): e12693. https://doi.org/10.1111/jfr3.12693

[9] UN. (2015). Sendai framework for disaster risk reduction 2015-2030. United Nations - Headquarters, United Nations Office for Disaster Risk Reduction, New York.

[10] Austin, K.F., McKinney, L.A. (2016). Disaster devastation in poor nations: The direct and indirect effects of gender equality, ecological losses, and development. Social Forces, 95(1): 355-380. https://doi.org/10.1093/sf/sow056

[11] Juran, L., Trivedi, J. (2015). Women, gender norms, and natural disasters in Bangladesh. Geographical Review, 105(4): 601-611. https://doi.org/10.1111/j.19310846.2015.12089.x

[12] Dodman, D., Leck, H., Rusca, M., Colenbrander, S. (2017). African urbanisation and urbanism: Implications for risk accumulation and reduction. International Journal of Disaster Risk Reduction, 26: 7-15. https://doi.org/10.1016/j.ijdrr.2017.06.029

[13] Ajaero, C.K. (2017). A gender perspective on the impact of flood on the food security of households in rural communities of Anambra state, Nigeria. Food Security, 9(4): 685-695. https://doi.org/10.1007/s12571-0170695-X

[14] Neumayer, E., Plümper, T. (2007). The gendered nature of natural disasters: The impact of catastrophic events on the gender gap in life expectancy, 1981-2002. Annals of the Association of American Geographers, 97(3): 551566. https://doi.org/10.1111/j.1467-8306.2007.00563.x

[15] Kwan, C., Walsh, C.A. (2007). Seniors' disaster resilience: A scoping review of the literature. International Journal of Disaster Risk Reduction, 25: 259-273. https://doi.org/10.1016/j.ijdrr.2017.09.010

[16] Caruson, K., Alhassan, O., Ayivor, J.S., Ersing, R. (2014). Disaster and development in Ghana: Improving disaster resiliency at the local level. In: Kapucu N., Liou K. (eds) Disaster and Development. Environmental Hazards. Springer, Cham, pp. 273-287. https://doi.org/10.1007/978-3-319-04468-2_16

[17] WorldBank. (2011). World development report 2012: Gender equality and development. Washington: World Bank.

[18] Ahonsi, B.A. (1995). Gender relations, demographic change and the prospects for sustainable development in Africa. Africa Development / Afrique et Développement, 20(4): 85-114

[19] Okafor, E.E., Abdulazeez, Y. (2007). Gender-sensitive projects for sustainable development in Nigeria: A critical assessment. Journal of Social Sciences, 15(3): 235-248. https://doi.org/10.1080/09718923.2007.11892588

[20] Jones, P. (2017). Formalizing the informal: Understanding the position of informal settlements and slums in sustainable urbanization policies and strategies in Bandung, Indonesia. Sustainability, 9(8): 1436. https://doi.org/10.3390/su9081436

[21] Ogunyankin, G.A. (2019). Postcolonial approaches to the study of African politics. Oxford Research Encyclopedia of Politics. https://doi.org/10.1093/acrefore/9780190228637.013.83 0

[22] Fothergill, A. (1998). The neglect of gender in disaster work: An overview of the literature. The Gendered Terrain of Disaster: Through Women's Eyes. Westport, CT, Praeger Publishers, pp. 11-25. https://www.researchgate.net/profile/Alice-

Fothergill/publication/238347161_The_neglect_of_gen der_in_disaster_work_An_overview_of_the_literature/li nks/5575b99608aeacff1ffdcfee/The-neglect-of-genderin-disaster-work-An-overview-of-the-literature.pdf.

[23] Ogunyankin, G.O.A.A. (2014). It's my right to fix the city: Women, class, and the postcolonial, politics of neoliberal urbanism in Ibadan, Nigeria. Graduate Program in Gender, Feminist and Women's Studies, York University, Toronto, Ontario.

[24] Aina, O.I. (1993). Mobilizing Nigerian women for national development: The role of the female elites. African Economic History, 21: 1-20. https://doi.org/10.2307/3601806

[25] Mba, N.E. (1982). Nigerian Women Mobilized: Women's Political Activity in Southern Nigeria, 19001965. University of California Institute of International 
Studies, Research Series, No. 48.

[26] Okonkwo, U.U., Ezeh, M.N.E. (2008). Implications of missionary education for women in Nigeria: A historical analysis. Journal of International Women's Studies, 10(2): 186-197. https://vc.bridgew.edu/jiws/vol10/iss2/15.

[27] Lamidi, E.O. (2016). Multilevel analysis of state variations in women's participation in household decision-making in Nigeria. Journal of International Women's Studies, 17(1): 186-201.

[28] Omotola, J.S. (2007). What is this gender talk all about after all? Gender, power and politics in contemporary Nigeria. African Study Monographs, 28(1): 33-46. https://doi.org/10.14989/68255

[29] Ikeda, K. (1995). Gender differences in human loss and vulnerability in natural disasters: A case study from Bangladesh. Indian Journal of Gender Studies, 2(2): 171193. https://doi.org/10.1177/097152159500200202

[30] Peek, L., Fothergill, A. (2008). Displacement, gender, and the challenges of parenting after Hurricane Katrina. $\begin{array}{lll}\text { NWSA } & \text { Journal, } & \text { 20(3): }\end{array}$ https://doi.org/10.1353/nwsa.0.0044

[31] Ajibade, I., McBean, G., Bezner-Kerr, R. (2013). Urban flooding in Lagos, Nigeria: Patterns of vulnerability and resilience among women. Global Environmental Change, 23(6): https://doi.org/10.1016/j.gloenvcha.2013.08.009

[32] McDowell, C.P., Andrade, L., O'Neill, E., O'Malley, K., O'Dwyer, J., Hynds, P.D. (2020). Gender-related differences in flood risk perception and behaviours among private groundwater users in the republic of Ireland. International Journal of Environmental Research and Public Health, 17(6): 2072. https://doi.org/10.3390/ijerph17062072

[33] Munn, Z., Peters, M.D.J., Stern, C., Tufanaru, C., McArthur, A., Aromataris, E. (2018). Systematic review or scoping review? Guidance for authors when choosing between a systematic or scoping review approach. BMC Medical Research Methodology, 18(1): 143. https://doi.org/10.1186/s12874-018-0611-x

[34] Pham, M.T., Rajić, A., Greig, J.D., Sargeant, J.M., Papadopoulos, A., McEwen, S.A. (2014). A scoping review of scoping reviews: advancing the approach and enhancing the consistency. Research Synthesis Methods, 5(4): 371-385. https://doi.org/10.1002/jrsm.1123

[35] Peters, M.D.J. (2016). In no uncertain terms: The importance of a defined objective in scoping reviews. JBI Evidence $\quad$ Synthesis, $14(2)$ : $1-4$. https://doi.org/10.11124/jbisrir-2016-2838

[36] Peters, M.D.J., Godfrey, C.M., Khalil, H., McInerney, P.,
Parker, D., Soares, C.B. (2015). Guidance for conducting systematic scoping reviews. JBI Evidence Implementation, 13(3): 141-146. https://doi.org/10.1097/XEB.0000000000000050

[37] Amine, L.S., Staub, K.M. (2009). Women entrepreneurs in sub-Saharan Africa: An institutional theory analysis from a social marketing point of view. Entrepreneurship \& Regional Development, 21(2): 183-211. https://doi.org/10.1080/08985620802182144

[38] Dominic, A., Amodu, L., Azuh, A.E., Toluwalope, O., Oluwatoyin, M.A. (2017). Factors of gender inequality and development among selected low human development countries in sub-Saharan Africa. Journal of Humanities and Social Science (JOSR-JHSS), 21(2): 0107. https://doi.org/10.9790/0837-2202040107

[39] Enete, A.A., Obi, J.N., Ozor, N., Mba, C.L. (2016). Socioeconomic assessment of flooding among farm households in Anambra state, Nigeria. International Journal of Climate Change Strategies and Management, 8(1): 96-111. https://doi.org/10.1108/IJCCSM-07-20140084

[40] Nnadi, O.I., Liwenga, E.T., Lyimo, J.G., Madukwe, M.C. (2019). Impacts of variability and change in rainfall on gender of farmers in Anambra, Southeast Nigeria. Heliyon, 5(7): e02085. https://doi.org/10.1016/j.heliyon.2019.e02085

[41] Akintoye, O.A., Eyong, A.K., Effiong, D.O., Agada, P.O., Digha, O.N. (2016). Socio-Economic implications of recurrent flooding on women development in Southern Ijaw local government area, Bayelsa State, Niger Delta Area of Nigeria. Journal of Geoscience and Environment Protection, 4(8): 33-46. https://doi.org/10.4236/gep.2016.48004

[42] Ibrahim, S.S., Ozdeser, H., Cavusoglu, B. (2019). Vulnerability to recurrent shocks and disparities in gendered livelihood diversification in remote areas of Nigeria. Environmental Science and Pollution Research, 26(3): 2939-2949. https://doi.org/10.1007/s11356-0183854-5

[43] Akinsemolu, A.A., Olukoya, O.A. (2020). The vulnerability of women to climate change in coastal regions of Nigeria: A case of the Ilaje community in Ondo State. Journal of Cleaner Production, 246: 119015. https://doi.org/10.1016/j.jclepro.2019.119015

[44] Nhamo, G., Muchuru, S., Nhamo, S. (2018). Women's needs in new global sustainable development policy agendas. Sustainable Development, 26(6): 544-552. https://doi.org/10.1002/sd.1717 